\title{
Navigating between Opportunities and Risks: The Effects of Hybridity for Social Enterprises Engaged in Social Innovation ${ }^{*}$
}

\section{ABSTRACT}

This article focuses on the hybridity of social enterprises, organizations that strive to create social and economic value simultaneously. It analyses how social entrepreneurs and local government deal with the hybridity resulting from mixing these two opposing values and what it means for social enterprises' contributions to processes of social innovation, e.g. new ways of dealing with societal problems using innovative constellation of organizations and other actors. The article discusses the results of a study of social enterprises in and around the cities of Rotterdam, The Hague and Dordrecht in the Netherlands and by doing so looks at an urban subset of social enterprises engaged in social innovation. In the underlying study, document analysis, interviews and a survey were used to identify what drives social entrepreneurs to engage in processes of social innovation, how they generate results and how they deal with the tensions due to hybridity. The article discusses the positive and negative effects of hybridity affecting social enterprises and describes avenues for further research on the subject.

\section{KEY-WORDS}

SOCIAL ENTERPRISE, SOCIAL INNOVATION, HYBRIDITY, HYBRID ORGANIZATION

An earlier version of this article was presented at the 6th EMES International Research Conference on Social Enterprise and was subsequently selected for publication on the EMES website (Karré and Mossel, 2017). 


\section{Introduction}

This article focusses on three key concepts: social enterprises, social innovation and hybrid organizations. Social enterprises integrate "economic and social value creation" (Mair and Martí, 2006: 36). According to the widely used EMES definition (Defourny and Nyssens, 2013; Pestoff, 2013), their primary goal is to generate social impact rather than profit for the company's owners or shareholders (Sacchetti and Campbell, 2014). They achieve this by trading goods and services on the market in an enterprising and innovative manner. Profits are mainly used to achieve social goals and the organization's management is transparent about its actions and is accountable to its employees, customers and other stakeholders.

Social enterprises try to contribute to the common good by creating public value through commercial activities at the interface of government, market and society (Defourny, Hulgård and Pestoff, 2014). In other words, they are engaged in processes of social innovation. Those are new approaches for dealing with social challenges that are "created mainly by networks and joint action in social realms beyond business and government routines [and that], at any given moment, raise the hope and expectations of progress towards something 'better' (a more sustainable/democratic/ effective society)" (Brandsen et al., 2016: 6-7).

Social innovation is "primarily aimed at improving social outcomes and creating public value" (Cels, Jong and Nauta, 2012: 4). Its ultimate goals are to develop "new ideas that work to meet pressing unmet needs and improve peoples' lives" (Mulgan, 2007: 7), and "innovations that are social in both their ends and their means" (Mulgan, 2015: x).

Social innovation is not only about developing a new kind of product or solution to a societal ill but also refers to the process that leads to it. The ultimate goal of social innovation is twofold: "[...] finding better ways to meet human needs and [...] strengthening bonds of commitment and solidarity" (Mulgan, 2015: $\mathrm{x}$ ). This means that the process leading towards social innovation entails new ways of cooperation and partnership between actors on an equal footing. Other forms of social innovation, besides social entrepreneurialism, include activities undertaken by citizens' initiatives and cooperation between various societal partners in living labs, aimed at experimentation and learning.

Social entrepreneurs engage in social innovation by combining two contradictory logics: the entrepreneurial and the social welfare logic, which can be regarded as each other's antonyms. As an effect of this, social enterprises "(1) involve a variety of stakeholders, (2) pursue multiple and often conflicting goals and (3) engage in divergent or inconsistent activities" (Mair, Mayer and Lutz, 2015: 714). They are hybrid organizations (Battilana and Lee, 2014; Doherty, Haugh and Lyon, 2014; Pestoff, 2014; Teasdale, 2012a; 2012b), "heterogeneous arrangements, characterized by mixtures of pure and incongruous origins, (ideal) types, 'cultures', 'coordination mechanisms', 'rationalities', or 'action logics"' (Brandsen, van de Donk and Putters, 2005: 750).

As is the case for hybrid organizations generally (Brandsen and Karré, 2011; Karré, 2011), their hybrid character is both a blessing and a curse for social enterprises. In their overview of hybridity's 
positive and negative effects for social enterprises, Doherty, Haugh and Lyon (2014) describe that combining an entrepreneurial and a social welfare logic creates a number of opportunities: it can foster the kind of synergy and innovation through which social entrepreneurs can really make a difference in tackling social problems. After all, its hybrid character is the essence and the unique selling point of social entrepreneurship. Without combining contradictory logics, social enterprises would not be able to achieve the social innovations they strive for.

However, hybridity can also lead to a number of risks for social enterprises in the creation of social innovation, Doherty, Haugh and Lyon (2014) write, such as mission drift, legitimacy and accountability issues and conflicts between goals and values. It is also a main source of the ambiguity and confusion surrounding social entrepreneurship as narrative and analytical concepts (Teasdale, 2012b). This often makes it difficult for social entrepreneurs to come up with a convincing narrative of what they are doing and how this helps in creating social innovation. This ambiguity also makes it difficult for researchers to map social enterprises (Lyon ans Sepulveda, 2009; Dart, Clow and Armstrong, 2010), a challenge also encountered in this instance (see Section 3 on research strategy).

Social entrepreneurs face the challenge of navigating between the opportunities and risks the hybrid character of their organization poses, while at the same time never losing sight of their ultimate goal, achieving meaningful social innovation. This article presents the findings of a study on how hybridity can be both an opportunity as well as a risk to social innovation by social entrepreneurs. This study was undertaken in three regions of the Netherlands: the RotterdamRijnmond area (Rotterdam and surroundings), the Haaglanden area (The Hague and surroundings) and the Drechtsteden area (Dordrecht and surroundings).

In the Netherlands, there is increasing political and media attention for social initiatives at the local level, whereby citizens themselves take responsibility to address social issues (Uitermark, 2012; Boer and Lans, 2014; Miazzo and Kee, 2014; Schleijpen and Verheije, 2014). Urban neighbourhoods and communities are seen as important laboratories or breeding grounds for new social and economic practices under the label of social innovation. The hope is that social entrepreneurs will play an important role in urban regeneration and development besides the more traditional actors of governments and property developers (Franke, Niemans and Soeterbroek, 2015).

It is interesting to examine the role social enterprises can play in social innovation and how they deal with the effects of their hybridity, as each municipality in the newly decentralized Dutch system is now responsible for how and by whom social services are provided. Social entrepreneurs see this as business opportunities, for example in providing work integration services for groups that find it difficult to obtain employment on the regular labour market, such as former delinquents. That is why the four biggest cities of the country, Amsterdam, Rotterdam, Utrecht and The Hague, as well as many smaller municipalities throughout the country, are now exploring ways in which social enterprises can play a role as part of the so called "welfare mix" (Evers, 1990) of several, public and private organizations, that provide fundamental social services. These discussions have to be seen in the light of fiscal austerity (municipalities are looking at ways to save money) but also in 
the light of the emergence of new kinds of social innovation described before and the political and media attention they generate.

This article is based on a qualitative study of 37 social enterprises in three regions of the Netherlands (through document analysis, interviews and a survey), interviews with representatives from local governments and a focus group consisting of social entrepreneurs and representatives from various municipalities ${ }^{1}$. It will address the following four research questions:

1. Why do social entrepreneurs decide to engage in processes of social innovation?

2. How are they trying to achieve social innovation?

3. In how far is hybridity an issue in this process?

4. What is the relationship between the social entrepreneur and local government in this process?

This article is structured as follows: it first describes the hybrid character of social enterprises and the effects of their hybridity in more detail. It then provides a summary of how the underlying research was conducted, followed by a presentation of the main findings. The article concludes with a discussion of the effects of hybridity for social entrepreneurs engaged in processes of social innovation and possible avenues for further research.

\section{The hybridity of social enterprise}

The introduction to this article already described that social enterprises engage in social innovation by creating public value through commercial activities at the interface of government, market and society. The first is often described as the public, the second as the private and the last as the Third sector of our economy, consisting of voluntary and community organisations. In theory, organizations operating in these sectors are different from each other on a variety of dimensions (see table 1). However, these are ideal types. Organizational reality is far more complex, fuzzy and hybrid (Christensen and Lægreid, 2010; Emery and Giauque, 2014; Skelcher and Smith, 2014; Anheier and Krlev, 2015; Denis, Ferlie and van Gestel, 2015; Seibel, 2015a, 2015b).

Social enterprises are prime examples of organizations that do not fit into the traditional categories of public, private and Third sector organizations. They straddle the boundaries of the three sectors and mix the characteristics of the ideal types of organizations that can be found there. They combine economic (or market-sector) goals with the social welfare goals more commonly at play in the public and the Third sector. They mix public funding with private earnings and charitable donations, and combine public, private and Third sector coordination mechanisms. This also means that they must somehow unite the core values (i.e. organizational cultures) dominant in

An earlier version of this article was presented at the 6th EMES International Research Conference on Social Enterprise and was subsequently selected for publication on the EMES website (Karré and Mossel, 2017). 
each of these sectors and combine conflicting institutional logics, i.e. a market or commercial logic and a "social care" logic aimed at creating social value (Pinch and Sunley, 2015). This also makes the governance of such hybrid organizations a challenging endeavour (Cornforth and Spear, 2010; Spear, Cornforth and Aiken, 2014).

Table 1. Characteristics of public, private and Third sector organizations

\begin{tabular}{llll}
\hline & Public & Private & Third Sector \\
\hline Resources & General allocation & Earnings on marketplace & $\begin{array}{l}\text { Donations, subsidies and } \\
\text { voluntary contributions }\end{array}$ \\
\hline Goals & Public good and welfare & Profit maximization & $\begin{array}{l}\text { Specific to groups, situation, } \\
\text { and environment, contribute } \\
\text { to public good and welfare }\end{array}$ \\
\hline $\begin{array}{l}\text { Coordination } \\
\text { mechanisms }\end{array}$ & $\begin{array}{l}\text { Politics and public } \\
\text { administration }\end{array}$ & $\begin{array}{l}\text { Competition on the market } \\
\text { place }\end{array}$ & $\begin{array}{l}\text { Formal and informal } \\
\text { influence of societal } \\
\text { stakeholders }\end{array}$ \\
\hline $\begin{array}{l}\text { Organizational culture } \\
\text { and action logics }\end{array}$ & Hierarchy, legality, equality & $\begin{array}{l}\text { Entrepreneurialism, } \\
\text { efficiency, effectiveness }\end{array}$ & Trust \\
\hline
\end{tabular}

Source: Brandsen \& Karré, 2011: 829.

Research on the hybridity of social enterprises is still in its early stages (Doherty, Haugh and Lyon, 2014; Teasdale, 2012b). However, there is quite some insight on hybrid organizations in general (cf. Brandsen and Karré, 2011; Karré, 2011) and more and more studies on hybridity and social enterprises specifically (Teasdale, 2012a; Battilana and Lee, 2014; Ebrahim, Battilana and Mair, 2014; Mair, Mayer and Lutz, 2015; Pinch and Sunley, 2015; Schmitz, 2015). Insights from all of these sources have been brought together in a systematic review by Doherty, Haugh and Lyon (2014), who describe that hybridity will positively (in the sense of creating opportunities) and negatively (in the sense of creating risks) effect a social enterprise's (1) mission, (2) its financial resources and (3) its human resources (see table 2). What follows is a summary of the effects of hybridity as identified by Doherty, Haugh and Lyon.

Table 2. Positive and negative effects of hybridity for social enterprises

\begin{tabular}{lll}
\hline & Positive effect & Negative effect \\
\hline Mission & Synergy, innovation & $\begin{array}{l}\text { Ambiguity, accountability problems, } \\
\text { mission drift }\end{array}$ \\
\hline Financial resources & Different sources for funding & Constraints in access to finance \\
\hline Human resources & Diverse staff under unifying mission & $\begin{array}{l}\text { Value conflicts, market distortion due to } \\
\text { use of 'free' staff }\end{array}$ \\
\hline
\end{tabular}

Source: based on Doherty, Haugh and Lyon (2014) 


\subsection{Social enterprise mission}

Social enterprises aim to achieve social goals by following an economic approach. This combination of a social and an economic outlook can lead to synergy and innovation, e.g. by leading to more efficient or effective work practices or to more socially-minded and ethical business practices. Other innovative strategies employed by social enterprises and described by Doherty, Haugh and Lyon (2014) based on their literature review, are new resource configurations, novel governance structures and strategic innovations, leading to new markets, products and services.

However, combining market and social logics will not always result in a harmonious marriage, as the needs of an organization's clients and the needs of other stakeholders (e.g. investors) can conflict. A combination of social and economic goals, e.g. commercial opportunity exploitation and pursuit of social mission, can also result in an ambiguous and diffuse mission, mimicking the ambiguity surrounding social enterprise and social entrepreneurship as theoretical concepts in general.

These challenges make it difficult for social entrepreneurs to communicate a convincing narrative of what they and their organizations are doing or plan to achieve and, for accountability purposes, what they have already achieved. As a result, many social entrepreneurs share a feeling of not being understood and adequately supported by actors they depend upon to make their organization's mission a success, such as local authorities, the financial system, the legal profession and the public at large.

Another possible negative effect of hybridity in social enterprises, as in hybrid organizations in general, is that of mission drift, when one of the multiple logics or goals of the organization is starting to dominate or displace the others. This can be the case when for example the organization's social objectives are sacrificed to achieve financial sustainability or when its pursuit of social goods starts to conflict with a managerial rationality prioritizing financial objectives. Mission drift can put the organization's legitimacy with its stakeholders under pressure and jeopardize the whole identity of the organization as a social enterprise.

\subsection{Social enterprise and financial resources}

As they operate between state, market and civil society, social enterprises have different potential sources for funding, write Doherty, Haugh and Lyon (2014). This can be seen as a distinct advantage for social enterprises over their governmental, private sector or civil society counterparts, as it increases the organization's agility and prevents it becoming dependant on only one (type of) investor.

But its ambiguous and diffuse character as a hybrid organization can also make it harder for a social enterprise to acquire the funds it needs to operate. It makes it more difficult to describe the organization's goals and activities in terms potential investors would react to. Also, many social enterprises, especially when they are non-profit enterprises, cannot access the equity market and be public listed. This would 
reduce their ability to get financial support from investors. Other characteristics of social enterprises also make them less interesting for commercial investors, e.g. that shareholder value is not their first and foremost concern, that they will generate less profit than with full economic costing and that their return on investment can take longer to materialize. Social enterprises are often forced to make a trade-off between their commercial and their social priorities. Reconciling them is only possible by transferring these higher costs on the organization's customers and investors.

\subsection{Social enterprise and human resource mobilization}

A final possible source of tensions due to hybridity as identified by Doherty, Haugh and Lyon (2014), concerns the human resource strategy of social enterprises. A positive effect of hybridity could be that social enterprises attract people with an array of backgrounds and many different fields of expertise, all connected by a shared vision on making the world a better place. The mission of a social enterprise can form a powerful motivation for social and business-minded staff alike.

But hybridity can also lead to tensions with regards to an organization's human resources. One possible source of conflict is that, while finding staff with the appropriate skills and competences is a challenge in itself, the logics and values of more socially minded and more business-minded employees might grow at odds with each other, resulting in fights for supremacy. Besides the risk of conflict, this also poses the danger of mission drift, as the fight for supremacy may end in one set of logic and values gaining the upper hand.

Another possible source of conflict arises due to the diversity of staff. Most social enterprises only have a small number of paid staff and use unpaid volunteers. This not only poses a threat to the continuity of the organization, as volunteers can withdraw their work at any time, but can also lead to jealousy between these two groups.

Also the roles people play within a social enterprise can clash with each other. Because of the organization's hybridity, the distinction between client and beneficiary stakeholder is often blurred, for example in social enterprises that help the long-term unemployed regain a place on the labour market. This means that the very same person is at one time seen as a client (with a focus on personal development) and at another time as an employee/volunteer (with a focus on performance). The use of clients in the commercial activities of a social enterprise can also lead to criticism by a social enterprise's commercial rivals about market distortion: clients are more or less "free" personnel for a social enterprise, giving it a competitive advantage in comparison with a regular business that needs to pay its staff.

\section{Research strategy}

This section describes how the data was collected for this article. Four steps were followed: (1) social enterprises were mapped, (2) interviews were conducted, (3) a survey was set out and (4) a focus group was organized. Below each step is described in more detail. Because research on social 
enterprises in the Netherlands is scarce and because there is quite some ambiguity about the term, an exploratory qualitative research design was chosen with the aim to better understand what a social enterprise is in the Dutch context and how social enterprises deal with hybridity in processes of social innovation. The goal of this article is not to draw a representative picture of all social enterprises in the Netherlands nor to generate a quantitative overview of the social enterprise market.

In the Netherlands, there is no specific policy framework or separate legal status for social enterprises. There is a wide variety of organizations that call themselves social enterprises though it is often not clear why they do so. Social enterprises can have a wide array of legal forms. They can, as commercial enterprises, opt for the forms of a private limited liability company (besloten vennootschap, BV) or that of a public company (naamloze vennootschap, NV). But they can just as well adopt the form of an association (vereniging), foundation (stichting) or cooperative (coöperatie). It is also possible for an individual social entrepreneur to provide services on a freelance basis as a self-employed without staff (zelfstandige zonder personeel) or ZZP-er for short. Several ZZP-ers can enter into a general partnership, in Dutch described as a vennootschap onder firma (or VOF). In practice, that means that virtually any organization can call itself a social enterprise. There also is no generally accepted overview or list available of Dutch "social enterprises" that could have served as a starting point for this research. Therefore, as a first step in the research underlying this article a mapping exercise was conducted. At this stage, research was confined to the city of Rotterdam, so the aim of this mapping exercise was to generate an overview of social enterprises there; only later was the scope of the research broadened to also include the social enterprises in the Haaglanden area (The Hague and surroundings) and the Drechtsteden area (Dordrecht and surroundings).

The mapping exercise used two already available overviews of organizations as a starting point. The first is generated by the Dutch Tax Authority and lists all organizations that can receive tax-exempt donations. The second list was compiled by MAEXchange ${ }^{2}$, a website where organizations engaged in processes of social innovation are showcased to prospective investors. Both these overviews list organizations that can be seen as "social initiatives" in a broad sense, that is organizations that mostly focus on social goals. These can be social enterprises, but also churches, cooperatives and citizens' initiatives are included in these lists. This meant that the organizations on both lists had to be closely examined in order to identify those organizations that fitted the EMES definition of a social enterprise as described in the introduction. For this, information provided on the organizations' own websites and social media was used. Obviously, this was no straightforward task due to the ambiguity of the definition of social enterprise and the sparseness of information. Even though a broad approach was chosen, it is possible that some social enterprises were missed during this process.

Besides studying the two already mentioned overviews of organization, a list was compiled based on an internet search of organizations that called themselves social enterprises on their websites.

https://maex.nl 
Many of these had already been encountered on the two above mentioned lists, but not all. Again, each organization had to be examined carefully. For example, several management consultancies used the term social enterprise to describe what they were doing. Upon closer inspection, what their social purpose was and how they were working on creating social value was impossible to conceive however. Organizations that called themselves social enterprises but where there were doubts about the aptness of this labelling, were not included in the research.

As a result of this mapping exercise, 40 organizations were identified in Rotterdam alone that fell under the broad EMES-definition of a social enterprise. Of these, initially 10 organizations were contacted with a request for an interview aimed at generating better insights into how social enterprises work in practice and how social entrepreneurs deal with hybridity. The organizations chosen already existed for several years and it was expected that this would mean that they were already well documented and the social entrepreneurs at their helm have had the opportunity to reflect on their hybrid status. Of the organizations contacted, five agreed to a semi-structured interview of about an hour each (see an overview in the Appendix). It was also possible to interview the social entrepreneurs behind another organization that had only recently been established, as they had heard about the research project and were very eager to participate. The interviews focussed on the person of the social entrepreneur, the activities of the social enterprise, how the organization dealt with hybridity and on the relationship between the organization and the local government. In order to understand how the local government views the rise of social enterprises, two representatives of the municipality of Rotterdam were interviewed. Moreover, to incorporate the view of the national government, two representatives of the Ministry of the Interior and Kingdom Relations, who were part of the Netherlands' government's strategy to strengthen the country's cities and urban areas, were interviewed.

The social enterprises that declined the interview request did so citing lack of time as the main reason. According to those social entrepreneurs, they received far too many requests for interviews and meetings than they could master. They also saw no direct benefit in talking to researchers: every hour spent on an interview was an hour she could not use to earn money, one social entrepreneur explained for example. Even though this had originally been the plan, because of these difficulties, no more interviews beyond the initial six were conducted but a survey was designed. This had two reasons: first, it would make it possible to collect data from many more social entrepreneurs than through interviews; second, it would take less time to social entrepreneurs to participate in the research. A survey consisting of 12 questions $^{3}$ was devised that could be filled in in about 10-15

(1) What is the name of the initiative?, (2) in which year has it been established?, (3) in which sector(s) is the initiative active?, (4) what was the main reason to establish the initiative?, (5) what are its activities?, (6) what are its sources of income?, (7) how does the initiative make the lives of the target group better?, (8) what is the reach of the initiative?, (9) what was your personal motivation to become active?, (10) is there a tension between social and economic activities, action logics, etc. in the initiative and how do these manifest themselves?, (11) with which other difficult trade-offs do you have to deal?, (12) are you in contact with the municipality and how do you experience this contact? 
minutes. A link to this survey was sent by e-mail to all 40 social enterprises in Rotterdam that had been identified during the mapping exercise. Of these, 11 social entrepreneurs filled in the survey (see an overview in the appendix).

In the meantime, due to interviews with representatives of the municipality of The Hague and an encounter with two social entrepreneurs with a big personal network in Dordrecht, it became possible to expand the scope of this research to the Haaglanden (The Hague and surroundings) and Drechtsteden (Dordrecht and surroundings) regions as well. In both cases, due to time constraints no new mapping exercise was conducted but the researchers decided to rely on the insights and network of those interviewed. In the case of The Hague, eleven social entrepreneurs were contacted and six filled in the survey (see an overview in the appendix). In the case of the Drechtsteden an invitation to fill in the survey was sent out by the social entrepreneurs described above themselves which led to 14 social entrepreneurs filling in the survey (see an overview in the Appendix).

In total, data of 37 social enterprises were collected:

- Interviews conducted with social entrepreneurs (Rotterdam): 6

- Social enterprises that filled in our survey (Rotterdam): 11

- Social enterprises that filled in our survey (The Hague): 6

- Social enterprises that filled in our survey (Rotterdam): 14

Based on the insights from the interviews and the survey and after having compared them with the literature on social enterprises and their hybrid status, a first analysis of the data was conducted and discussed with several social entrepreneurs and representatives of the municipalities during a focus group conversation lasting 1.5 hours. At this meeting, four social entrepreneurs were present as well as six representatives of the municipalities of Rotterdam and The Hague. The aim of this focus group was twofold: first, it should provide the researchers with critical feedback on their preliminary analysis. Second, it was supposed to help social entrepreneurs and municipality representatives to engage in an open dialogue about their wishes and expectations from one another, as it had become clear during the research that often both parties do not see eye to eye.

\section{Findings}

\subsection{Reasons for social entrepreneurs to engage in social innovation}

There are several reasons for social entrepreneurs to engage in processes of social innovation, which are all closely connected to personal experiences and life events.

A first set of reasons is connected to the social entrepreneur's professional background. Of the six social entrepreneurs which were interviewed in Rotterdam, four had a background in the sector their enterprise was now active in. Only one came from the commercial sector and had decided to make a switch, as she could no longer identify with the culture and values of a stock market listed enterprise. Of the entrepreneurs with a background in the same sector, one had been running another 
organization for sheltered employment before. Another still worked as a policeman besides being a social entrepreneur and used the insights he gained in this position on how to deal with youthful delinquents for his new role. Two social entrepreneurs had a very similar background and had both worked for more traditional social welfare providers before, but had decided to resign and to start their own social enterprise and set their own course aimed at social innovation. The main reason was that they no longer identified with their employers' strategy. They saw themselves increasingly at odds with the orthodoxy within the organization which, in their eyes, made meaningful social innovation impossible.

They main reason for the interviewed social entrepreneurs to become active was that they spotted a gap in the market. According to them, a new, more innovative approach to social welfare provision was a necessity but so far none of the traditional players offered such an approach. The social entrepreneurs were convinced that combining their social goals with an economic outlook was necessary to make sure that those goals would be reached. Working in a commercial manner was the means that helped the entrepreneurs achieve their social goals as combining social and economic goals created synergies. For example, one of the interviewees explained that she had become frustrated with her organization mainly focussing on what her clients could no longer do rather than help them develop their talents. She wanted to help clients build their self-esteem but found it hard to sustain this "unorthodox" approach within the organization. So she quit and started her own enterprise, which mainly focusses on helping clients to discover and strengthen their talents. This is done by combining activities subsidized by the municipality with carrying out activities for commercial customers. To be able to achieve this goal and because she liked being her own boss, she had opted for the model of a social enterprise to achieve her goals.

The results from the survey support the results from the interviews with regard to the importance of the professional background of the social entrepreneurs. From the nine social entrepreneurs in Rotterdam that had filled in the survey, one had been a manager at a big social welfare provider before and three combined their work as a social entrepreneur with commercial activities, often in the same sector. For example, one social entrepreneur who ran a catering organization employing people with poor job prospects on the regular labour market also ran a company providing health and dietary advice. Her commercial activities provided her with insights she could use in her social innovation activities and her experiences had triggered her to become active.

This was also the case for five of the six social entrepreneurs from The Hague who completed the survey, who were also engaged in other, more commercial activities as consultants. In the Drechtsteden region, two of the fourteen social entrepreneurs explicitly stated that they had a background in the sector their organization was active in. The same may well have been true for a larger number, but because of the limitations of the survey, we cannot know for sure.

Another big driving force that can trigger a social entrepreneur to become active in the creation of social innovation, are experiences in their personal life. One social entrepreneur and artist interviewed in Rotterdam explained that he made his decision to engage in social innovation when 
he moved into a poorer part of the city and witnessed the poverty and deprivation first-hand. As this was the neighbourhood where his children would grow up, he decided that action was necessary and had begun to employ local residents with poor job prospects to help him with his art projects. Another social entrepreneur echoed this sentiment: the birth of her children had made her rethink her goals and ambitions in life and let her decide to start a company aimed at helping others. Yet another entrepreneur explained how personal tragedy had made her decide to become a social entrepreneur. She told of her brother who had a difficult start in life. This had made her decide to help others who were not able to help themselves.

Evidence for the importance of life events as reasons to engage in social innovation was also found in the surveys. One social entrepreneur in Rotterdam stated that his decision to start an initiative aimed at elderly people suffering from loneliness was that he saw his own grandmother feeling lonely after many of her friends had passed away. Another social entrepreneur in Rotterdam saw his company and his marriage fail and spent some years living on the streets. This made him decide to start a social enterprise helping homeless people after he himself had landed on his feet again. In Dordrecht, a social entrepreneur related her story of suffering brain damage and of how complicated it is to suffer from an affliction without physical traces. She now runs a social enterprise aimed at women who also have to deal with what she calls "invisible limitations".

\subsection{Activities of social entrepreneurs engaged in social innovation}

An examination of the activities undertaken by the social entrepreneurs in Rotterdam, The Hague and Dordrecht aimed at achieving social innovation, shows a very diverse and fragmented picture. These activities ranged from repairing walking frames for the elderly to providing educational programmes for people who had problems finding jobs on the regular labour market. What all the social enterprises had in common is that they provided made-formeasure solutions for the problems of a certain group (e.g. lonely senior citizens, youths with a criminal background, women who did not speak Dutch because they had only recently arrived in the country, etc.).

All the social enterprises studied earned part of their income from the market place, i.e. remuneration for a range of goods and services provided to businesses and consumers. Many combined this income with municipal subsidies, mostly for providing sheltered work for groups with poor prospects on the regular labour market. Combining these two revenue streams was often complicated. A first complication concerned the red tape related to working for a municipality as these organizations had to adhere to strict accountability requirements for the use of public money. A second complication concerned the expectations commercial customers often had with regards to the level of service they expected. One of the social entrepreneurs interviewed in Rotterdam explained for example, that commercial customers expect speedy delivery but it is complicated to guarantee that when working with volunteers. This social entrepreneur also explained that one of 
the goals of the organization was empowering volunteers, and while she saw benefits in having them participate in commercial activities, too much attention on the economic goals of the organization could lead to mission drift and to using volunteers as cheap labour.

\subsection{Hybridity as an issue in processes of social innovation}

The social enterprises examined in this study were a rather diverse bunch, ranging from small start-ups to big organizations spun out of local government. But whatever their organizational structure, all organizations had to deal with their hybrid character as social entrepreneurs engaged in both social and economic value creation. This was not always easy. One of the social entrepreneurs interviewed in Rotterdam complained that the concept of social enterprise was still virtually unknown in the Netherlands. Here, she explained, there still is a dichotomy between being socially minded and commercially minded and that many people think that social and economic activities cannot and should not be combined. Not only are hybrids often met with suspicion, she also learned that the hybridity of her organization made it difficult for her to describe what precisely she was doing as a social entrepreneur. It meant that in effect she felt that she could not do anything right, as there was always someone deriding her for being either too social or too commercial. She saw benefits in a hybrid position as a social enterprise (otherwise she would not have chosen it) but was also very aware of the possible negative effects of hybridity, e.g. distorting the market by keeping prices for services low through working with volunteers. This was especially an issue when the organization had to engage in activities which were maybe more commercial than social in nature but had to be done in order to bring money in to subsidize the more social activities.

Another social entrepreneur interviewed in Rotterdam explained that while he was of the opinion that while for him combining social and economic goals in creating social innovation was a natural mix and hence not a big problem, he himself lacked the expertise needed to run the commercial side of things. He was good at dealing with the organization's clients (former delinquents) but had no experience with running a company. Therefore, he had decided to employ somebody to look at the business side of operations.

Four social entrepreneurs in Rotterdam explained that while ideally the social and the commercial outlook in their operations were balanced, in reality the commercial side of things often was decisive. The amount of funds and work available, determined which social activities the organization could offer. Especially in the beginning, economic interests were more important than social ones while the organization was built from the ground up.

Also with regard to the effects of hybridity on social innovation by social enterprises, the findings from the survey echo those from the interviews. Of the social entrepreneurs in Rotterdam who filled in the survey, one explained that as she had only started her social enterprise last year, for now most of her time was spent finding funds. She regretted this, as it meant that she could spend less time with the group she wanted to help (people with poor job prospects on the regular labour market). Another Rotterdam social entrepreneur explained that he often had to choose between 
either being social or being commercially minded and that being both often was not possible. And a third echoed complaints about the lack of recognition for social enterprise in the Netherlands but stated that this was the only way to combine social and commercial values. In The Hague, one social entrepreneur explained that she could only afford being social as long as that did not endanger her commercial business interests and another that, because he had only recently started his social enterprise, at the moment the economic perspective trumped the social one. A commercial outlook kept the social activities of the organization afloat. In the Drechtsteden, the survey also showed social entrepreneurs struggling to find a good mix of the social and the commercial perspective. One social entrepreneur complained about the "pull of the market place" as the continuation of the organization's social activities depended on its economic success. And another social entrepreneur in Dordrecht related the problems of working in a commercial setting with clients whose work was subsidized by local government. She often had to defend herself for distorting the market by employing free staff, she explained.

\subsection{Relationship between social entrepreneurs and local government}

Because of the nature of their work and their activities, social entrepreneurs often have close contact with municipalities, who can be their partners and their customers. Social entrepreneurs often describe this relationship as difficult. One social entrepreneur from Rotterdam complained in the interview that she did not feel she was being taken seriously by the municipality. While politicians liked to visit her premises and being photographed with her and with the volunteers working at her organization, she experienced little to no support from city hall in her endeavours. Her organization was deemed too small and too amateurish to be hired by the municipality. Applying for subsidies from the municipality would be another way to generate funding but she had decided against that, as this would inevitably mean that she had to deal with what she perceived to be lots of red tape and excessive accountability procedures.

Also another social entrepreneur interviewed in Rotterdam was highly critical of the municipality, who he said operated in an ivory tower and had no idea of what was happening on the ground. He also did not feel he was being taken seriously. He too complained that he was often invited to meet and speak with people from the municipality but that they then always shirked from granting him business.

In the survey, the picture was mixed with regards to the relationship between social entrepreneurs and the municipality. In the Rotterdam survey, two social entrepreneurs reported their relationship with the municipality as "good", though four also complained that while the municipality shared their goals they did not yet work with them or grant them assignments. One social entrepreneur also complained that the municipality did not understand the benefit of a social enterprise and was mostly focussed on what an activity cost and not on what the social outcome would be. Another complained that he regularly had to deal with new civil servants at the municipality and missed a someone in the organization specifically assigned to deal with social enterprises. He also missed 
being recognized as a partner who could help the municipality tackle social problems.

Social entrepreneurs from The Hague provided little information about their relationship with the municipality in the survey but of the social entrepreneurs from Dordrecht, four describe their relationship with the municipality as "good", while three were critical. One social entrepreneur described feeling misunderstood and another complained that it often focussed too much on quantity than on quality, echoing sentiments we had heard in our interviews. Yet another complained that the municipality could do much more to help him achieve his social innovation goals.

To better understand the relationship between social entrepreneurs and the municipalities, we organized a focus group to discuss the findings from the interviews and survey. During the focus group meeting, it became apparent that social entrepreneurs and municipalities did not really understand each other, even though they share some of the same goals. Municipalities are still deciding what to make of initiatives that mix social and economic goals and are often either pigeonholing them as "social" or as "commercial" and fail to see them as the hybrids they are. Social entrepreneurs find it difficult to make sense of what municipalities do and to follow their logic as public institutions. They need the municipality to sustain their activities but often fail to grasp how government works and that public expenses need to be properly accounted for. Social entrepreneurs complain about rules and regulations when working together with municipalities but cannot manage without their help. Several of the social entrepreneurs present at the focus group complained that municipalities did not use them as a preferred customer for goods and services. Others would have liked the municipality to at least act as a so-called "launching customer", i.e. grant them business so that other potential customers see that the organization can be trusted. They failed to recognise that individual civil servants cannot make independent choices when it comes to spending money even on a small scale, for reasons including already being bound by long-term contacts, or a need for their suppliers to operate on a scale social entrepreneurs cannot meet.

\section{Conclusions and discussion}

This article examined what hybridity means for the social innovation activities carried out by social entrepreneurs, based on a study of social enterprises in three cities in the Netherlands. The following paragraph contains the conclusions on each of these questions and a discussion of them (see Table 3 for an overview). The final paragraph describes the challenges of doing research on social enterprises in the Netherlands and how future research could overcome them.

\subsection{The effects of hybridity for social entrepreneurs engaged in social innovation}

Professional or personal experiences with a certain target group or insight into their problems and challenges can be reasons for social entrepreneurs to become active in processes of social innovation. 
The activities the social entrepreneur undertakes to help the target group can be diverse, as most social entrepreneurs opt for made-to-measure interventions based on the specific needs of the target group and their own personal skills. The hybrid character of the social enterprise is often seen as key to produce meaningful social innovation, but it is difficult to pinpoint what exactly this innovation entails. Mostly it seems to be that the organization's target group can participate in commercial activities within the sheltered context of the social enterprise. By doing so, the organization's target group can develop skills that will help it to later find a job on the regular labour market. However, there is the danger that in times when commercial interests trump social ones, the organization's volunteers are mostly used as cheap labour and their reintegration onto the labour market ceases to be the number one goal of the social enterprise.

Not only the activities embarked on by social entrepreneurs in processes of social innovation are diverse. The same can be said of their revenue streams. Social enterprises mix different forms of income, such as market income and government subsidies. On the one hand, that is beneficial for the organization as it can compensate shortfalls in one revenue stream. But it can also lead to problems. Relying too heavily on municipal subsidies can lead to bureaucratisation because making use of public funds always comes with specific accountability requirements. Combining subsidies with market incomes can lead to mission drift, when acquiring income from commercial activities becomes more important than the organization's social focus. Ambiguity due to hybridity might frighten off possible investors when an organization is perceived as either too commercial (which makes municipalities and social funds shirk away from subsidizing) or as too social (which scares off private investors).

In general, social entrepreneurs see the hybrid character of their organization as a positive thing as it helps them reach their social goals. However, it can also make this process very complicated. Several of the social entrepreneurs told of the difficult trade-offs they had to make and that, at least in the short run, economic necessities still trumped their social ambitions. In addition, not every social entrepreneur has the skills and experience to combine a social and an economic outlook. Finally, hybridity can also lead to ambiguity, making it difficult to explain what the organization does and how it does it. This is especially problematic in a situation where social enterprises, their activities and their status as hybrid organizations are met with suspicion by the outside world.

A special relationship is that between social entrepreneurs on the one hand and local governments on the other hand. Social entrepreneurs expect much from the municipalities and see them as natural allies. It frustrates them when, in their eyes, they are not taken seriously by municipalities or only as props for a politician coming for a visit to make themselves look good. But also municipalities are often frustrated by the actions of social entrepreneurs, as they are taken to imply that they do not know or do not care how decisions are taken on the municipal level and which rules and regulations apply to the expenditure of public money.

This article shows that hybridity is an issue for social enterprises that, in order to achieve social innovation, combine a social with an economic outlook. Hybridity can help them in their efforts, 
but the social entrepreneurs involved have to work much harder to explain what they are doing and why it is beneficial to their societal cause.

Hybridity also has several downsides which can (as is always the case with hybrids) be seen as the opposites of its positive effects: hybridity always is a "heads and tales issue" (Karré, 2011: 16), where pros and cons make up two sides of the same coin and thus inseparable. Ambiguity and mission drift are real dangers, as is market distortion. This means that social entrepreneurs have to be clear about the benefits their hybrid character has for their ability to achieve social innovation. They also have to understand the potential risks of hybridity and know how to tackle them. This means that while social entrepreneurs have to keep an eye on the big prize (the social innovation they want to achieve), they also have to carefully navigate between the opportunities and risks of hybridity. Only then will they not only be able to achieve meaningful social innovation, but they will also prevent being criticised for their hybrid character and strategy.

Table 3. Summary of findings

\begin{tabular}{|c|c|c|}
\hline & Positive effect & Negative effect \\
\hline \multirow[t]{2}{*}{ Mission } & $\begin{array}{l}\text { Hybridity makes made-to-measure } \\
\text { interventions possible for specific target } \\
\text { group. }\end{array}$ & $\begin{array}{l}\text { Ambiguity makes it hard to explain what the } \\
\text { organization does. }\end{array}$ \\
\hline & $\begin{array}{l}\text { Hybridity is seen as key to produce } \\
\text { meaningful social innovation, though what } \\
\text { that innovation entails precisely is less clear. }\end{array}$ & $\begin{array}{l}\text { Mission drift is a constant problem, as at } \\
\text { times commercial interests need to give } \\
\text { preference over social ones. }\end{array}$ \\
\hline \multirow[t]{2}{*}{$\begin{array}{l}\text { Financial } \\
\text { resources }\end{array}$} & $\begin{array}{l}\text { Social enterprises mix different forms } \\
\text { of income, such as market income and } \\
\text { government subsidies. This makes it possible } \\
\text { for the organization to compensate shortfalls } \\
\text { in one revenue stream. }\end{array}$ & $\begin{array}{l}\text { Relying too heavily on municipal subsidies } \\
\text { can lead to bureaucratisation. } \\
\text { Combining subsidies with market incomes } \\
\text { can lead to mission drift, when acquiring } \\
\text { income from commercial activities becomes } \\
\text { more important than the organization's social } \\
\text { focus. }\end{array}$ \\
\hline & & $\begin{array}{l}\text { Ambiguity due to hybridity might frighten } \\
\text { off possible investors when an organization } \\
\text { is perceived as either too commercial (which } \\
\text { makes municipalities and social funds shirk } \\
\text { away from subsidizing) or as too social } \\
\text { (which scares off private investors). }\end{array}$ \\
\hline Human resources & $\begin{array}{l}\text { When participating in commercial activities } \\
\text { within the sheltered context of a social } \\
\text { enterprise, the organization's target group can } \\
\text { develop skills that will help it to later find a } \\
\text { job on the regular labour market. }\end{array}$ & $\begin{array}{l}\text { The target group of the social enterprise } \\
\text { might be used as cheap labour in times when } \\
\text { commercial interests trump social ones. }\end{array}$ \\
\hline
\end{tabular}




\subsection{Limitations and avenues for further research}

Social innovation through social enterprise is no straightforward process. The same can be said about doing research on that matter. Because of their hybrid character, social enterprises are difficult phenomena to study. This is especially true in the Netherlands where there is no specific policy framework of separate legal statue for social enterprises (yet). Neither is there an unambiguous or broadly shared definition of what a social enterprise is, nor an overview of social enterprises and only very limited academic research. Social entrepreneurs are good at making their voices heard and have found allies, such as lobby organizations Ashoka, Social Enterprise NL, Social Impact Factory and various Impact Hubs, which help them sell themselves in a convincing manner. But much of the discussion about social enterprises still has the characteristics of a hype, with a whole industry around workshops, roundtables and inspirational sessions. Meanwhile there is confusion about the term and concept of social enterprise and limited insight in how social enterprises work and which societal impact they actually generate.

This situation makes it very difficult to operationalize the term "social enterprise" for research in the Dutch context. That is why this article opted for a rather broad definition, even though that meant that deciding which organizations to include was more arbitrarily than the author would have liked. This was none the less perceived as acceptable, as this article's goal was not to draw a representative picture of all social enterprises in the Netherlands, but rather to identify issues concerning their hybrid character, which future studies should draw more attention to. For this type of research, a more detailed definition of social enterprises in the Netherlands is needed, for which elements of the results from this article can be used as building blocks.

A second avenue of future research which could help to overcome the limitations of the results presented in this article, is to find methods which are better suited to study the hybrid character of social enterprise than interviews and surveys. In the Dutch context there is so much societal buzz around social entrepreneurs that they now often reject interview requests, citing that those keep them away from their entrepreneurial activities. This is why, besides doing interviews, we also sent out a survey. Because of their time restraints, more social entrepreneurs were willing to fill in a short questionnaire than to sit down for an interview. However, the instrument of the survey does not lend itself to collecting qualitative information the way an interview does. Most of the questions we wanted to ask were not straightforward enough for the answer to be jotted down quickly, but required more thought and often some coaxing by the researches to provide enough the comprehensive information needed to draw a rich picture.

Other research methods might be better suited in this context, for example Q-methodology. However, while there still is much research to be done to understand the hybrid character of social enterprises better and their role in social innovation, this article has started this discussion by identifying several issues for further study. 


\section{References}

Anheier, H. K., \& Krlev, G. (2015). Guest Editors' Introduction, International Studies of Management \& Organization, 45(3): 193-206. DOI: https://doi.org/10.1080/00208825.2015.1006026

Battilana, J., \& Lee, M. (2014a). Advancing Research on Hybrid Organizing - Insights from the Study of Social Enterprises, The Academy of Management Annals, 8(1): 397-441. DOI: https://doi.org/10.5465/19416520.20 14.893615

Boer, N. de, \& Lans, J. van der. (2014). DEcentraal: de stad als sociaal laboratorium. Amsterdam: Uitgeverij Atlas Contact.

Brandsen, T., van de Donk, W. \& Putters, K. (2005). Griffins or Chameleons? Hybridity as a Permanent and Inevitable Characteristic of the Third Sector, International Journal of Public Administration, 28(9-10): 749-765. DOI: https://doi.org/10.1081/PAD-200067320

Brandsen, T., Evers, A., Cattacin, S., \& Zimmer, A. (2016). Social Innovation: A Sympathetic and Critical Interpretation. In: T. Brandsen, S. Cattacin, A. Evers \& A. Zimmer (Eds.), Social Innovations in the Urban Context. Heidelberg: Springer Verlag GmbH u. Co., pp. 3-18. DOI: https://doi.org/10.1007/978-3-319-21551-8_1

Brandsen, T., \& Karré, P. M. (2011). Hybrid Organizations: No Cause for Concern?, International Journal of Public Administration, 34(13): 827-836. DOI: https://doi.org/10.1080/01900692.2011.605090

Cels, S., Jong, J. de, \& Nauta, F. (2012). Agents of Change: Strategy and Tactics for Social Innovation. Washington, DC: Brookings Institution Press.

Christensen, T., \& Lægreid, P. (2010). Complexity and Hybrid Public Administration-Theoretical and Empirical Challenges, Public Organization Review, 11(4): 407-423. DOI: https://doi.org/10.1007/s11115-010-0141-4

Cornforth, C., \& Spear, R. (2010). The governance of hybrid organizations. In: D. Billis (Ed.), Hybrid organizations and the Third sector. Challenges for practice, theory and policy. Houndmills Basingstoke: Palgrave Macmillan, pp. 70-90.

Dart, R., Clow, E., \& Armstrong, A. (2010). Meaningful difficulties in the mapping of social enterprises, Social Enterprise Journal, 6(3): 186-193. DOI: https://doi.org/10.1108/17508611011088797

Defourny, J., Hulgård, L., \& Pestoff, V. (2014). Social Enterprise and the Third Sector: Changing European landscapes in a comparative perspective. London and Ney York: Routledge.

Defourny, J., \& Nyssens, M. (2013). Social Co-operatives: When Social Enterprises Meet the Co-operative Tradition, Journal of Entrepreneurial and Organizational Diversity, 2(2): 11-32. DOI: https://doi.org/10.5947/jeod.2013.008

Denis, J.-L., Ferlie, E., \& van Gestel, N. (2015). Understanding hybridity in public organizations, Public Administration, 93(2): 273-289. DOI: https://doi.org/10.1111/padm.12175

Doherty, B., Haugh, H., \& Lyon, F. (2014). Social enterprises as hybrid organizations: A review and research agenda, International Journal of Management Reviews, 16(4): 417-436. DOI: https://doi.org/10.1111/ijmr.12028

Ebrahim, A., Battilana, J., \& Mair, J. (2014). The governance of social enterprises: Mission drift and accountability challenges in hybrid organizations, Research in Organizational Behavior, 34: 81-100. DOI: https://doi. org/10.1016/j.riob.2014.09.001

Emery, Y., \& Giauque, D. (2014). The hybrid universe of public administration in the 21 st century, International Review of Administrative Sciences, 80(1): 23-32. DOI: https://doi.org/10.1177/0020852313513378

Evers, A. (1990). Shifts in the Welfare Mix-Introducing a New Approach for the Study of Transformations in Welfare and Social Policy. In: A. Evers \& H. Wintersberger (Eds.), Shifts in the Welfare Mix. Their Impact on Work, Social Services and Welfare Policies. Frankfurt am Main: Sage Publications, pp. 7-30.

Franke, S., Niemans, J., \& Soeterbroek, F. (Eds.). (2015). Het nieuwe stadmaken. Van gedreven pionieren naar gelijk speelveld. Haarlem: trancity*valiz.

Karré, P. M. (2011). Heads and tails: both sides of the coin : an analysis of hybrid organizations in the Dutch waste management sector. The Hague: Eleven International Publishing. 
Karré, P. M., \& Mossel, V. (2017). Between a rock and a hard place. The hybrid character of social enterprises. EMES Conferences Selected Papers. Louvain-la-Neuve: EMES Research Network.

Lyon, F., \& Sepulveda, L. (2009). Mapping social enterprises: past approaches, challenges and future directions, Social Enterprise Journal, 5(1): 83-94. DOI: https://doi.org/10.1108/17508610910956426

Mair, J., \& Martí, I. (2006). Social entrepreneurship research: A source of explanation, prediction, and delight, Journal of World Business, 41(1), 36-44. DOI: https://doi.org/10.1016/j.jwb.2005.09.002

Mair, J., Mayer, J., \& Lutz, E. (2015). Navigating institutional plurality: Organizational governance in hybrid organizations, Organization Studies, 36(6), 713-739. DOI: https://doi.org/10.1177/0170840615580007

Miazzo, F., \& Kee, T. (2014). We own the city: enabling community practice in architecture and urban planning. Haarlem: trancity*valiz.

Mulgan, G. (2007). Social Innovation. What it is, why it matters and how it can be accelerated. London: The Young Foundation.

Mulgan, G. (2015). Foreword: The Study of Social Innovation - Theory, Practice and Progress. In: A. Nicholls, J. Simon, M. Gabriel \& C. Whelan (Eds.) New Frontiers in Social Innovation Research. Houndmills Basingstoke Hampshire $\&$ New York: Palgrave Macmillan, pp. $\mathrm{x}$-xx.

Pestoff, V. (2013). The Role of Participatory Governance in the EMES Approach to Social Enterprise, Journal of Entrepreneurial and Organizational Diversity, 2(2). DOI: https://doi.org/10.5947/jeod.2013.010

Pestoff, V. (2014). Hybridity, innovation and the third sector: The co-production of public services. In: J. Defourny, L. Hulgård \& V. Pestoff (Eds.), Social enterprise and the third sector : changing European landscapes in a comparative perspective. Abingdon, Oxon: Routledge, pp. 250-270.

Pinch, S., \& Sunley, P. (2015). Social enterprise and neoinstitutional theory: An evaluation of the organizational logics of SE in the UK, Social Enterprise Journal, 11(3): 303-320. DOI: https://doi.org/10.1108/SEJ-07-2014-0030

Sacchetti, S., \& Campbell, C. (2014). Creating Space for Communities: Social Enterprise and the Bright Side of Social Capital, Journal of Entrepreneurial and Organizational Diversity, 3(2): 32-48. DOI: https://doi.org/10.5947/ jeod.2014.012

Schleijpen, R., \& Verheije, M. (2014). Pioniers in de stad: wijkondernemers delen kennis en praktijk. Haarlem: trancity*valiz.

Schmitz, B. (2015). Beyond Structural Governance: Tension Moments and the Preservation of Core Values in Hybrid Organizations, International Studies of Management \& Organization, 45(3): 241-258. DOI: https://doi.org/10.1 080/00208825.2015.1006029

Seibel, W. (2015a). Studying Hybrids: Sectors and Mechanisms, Organization Studies, 36(6): 697-712. DOI: https://doi. org/10.1177/0170840615580005

Seibel, W. (2015b). Welfare Mixes and Hybridity: Analytical and Managerial Implications: 'Welfare Mix' and Hybridity: Divergent but Compatible Concepts, Voluntas, 26(5): 1759-1768. DOI: https://dx.doi.org/10.1007/s11266015-9617-8

Skelcher, C., \& Smith, S. R. (2014). Theorizing hybridity: Institutional logics, complex organizations, and actor identities: The case of nonprofits, Public Administration. 93(2): 433-448. DOI: https://doi.org/10.1111/padm.12105

Spear, R., Cornforth, C., \& Aiken, M. (2014). Major Perspectives on Governance of Social Enterprise. In: J. Defourny, L. Hulgård \& V. Pestoff (Eds.), Social enterprise and the third sector : changing European landscapes in a comparative perspective. Abingdon, Oxon: Routledge, pp. 133-156.

Teasdale, S. (2012a). Negotiating Tensions: How Do Social Enterprises in the Homelessness Field Balance Social and Commercial Considerations?, Housing Studies, 27(4): 514-532. DOI: https://doi.org/10.1080/02673037.2012.677015

Teasdale, S. (2012b). What's in a Name? Making Sense of Social Enterprise Discourses, Public Policy and Administration, 27(2): 99-119. DOI: https://doi.org/10.1177/0952076711401466

Uitermark, J. (2012). De zelforganiserende stad. In: Raad voor de Leefomgeving en Infrastructuur (Ed.) Essays toekomst van de stad. The Hague: Raad voor de Leefomgeving en Infrastructuur, pp. 5-9. 


\section{Appendix}

Table A. Social enterprises interviewed in Rotterdam and surrounding area

\begin{tabular}{|c|c|c|c|}
\hline & & Established & Description \\
\hline 1 & $\begin{array}{l}\text { Talentfabriek010 } \\
\text { (Rotterdam) }\end{array}$ & 2013 & $\begin{array}{l}\text { Talenfabriek } 010 \text { helps women to develop their talents } \\
\text { by having them participate in craft projects. }\end{array}$ \\
\hline 2 & $\begin{array}{l}\text { Heilige Boontjes } \\
\text { (Rotterdam) }\end{array}$ & 2014 & $\begin{array}{l}\text { Coffee bar which provides a job and schooling to } \\
\text { youths with a criminal past. }\end{array}$ \\
\hline 3 & $\begin{array}{l}\text { Vakbroeders } \\
\text { (Rotterdam) }\end{array}$ & 2014 & $\begin{array}{l}\text { Trains jobless youths to become house painters and } \\
\text { decorators. }\end{array}$ \\
\hline 4 & $\begin{array}{l}\text { DNA Charlois } \\
\text { (Rotterdam) }\end{array}$ & 2012 & $\begin{array}{l}\text { Provides job opportunities for people with poor job } \\
\text { prospects by letting them participate in art projects. }\end{array}$ \\
\hline 5 & $\begin{array}{l}\text { BuurCare } \\
\text { (Rotterdam) }\end{array}$ & 2016 & $\begin{array}{l}\text { Helps inhabitants of housing estates to develop the } \\
\text { skills to maintain their buildings, which also fosters } \\
\text { feelings of community and cohesion. }\end{array}$ \\
\hline 6 & $\begin{array}{l}\text { Stroomopwaarts } \\
\text { (Maassluis, } \\
\text { Vlaardingen en } \\
\text { Schiedam) }\end{array}$ & 2015 & $\begin{array}{l}\text { Provides sheltered workshops for the handicapped and } \\
\text { people with poor job prospects. }\end{array}$ \\
\hline
\end{tabular}


Table B. Social enterprises that filled in our survey (Rotterdam and surrounding area)

\begin{tabular}{llcl}
\hline 1 & Established & Description \\
\hline $\begin{array}{l}\text { Kookt } \\
2\end{array}$ & BuurtLAB & 2016 & $\begin{array}{l}\text { A caterer that employs people with poor job prospects, } \\
\text { helping them to develop professional cooking skills. }\end{array}$ \\
\hline 3 & $\begin{array}{l}\text { Stichting Het Lab } \\
\text { Rotterdam }\end{array}$ & 2013 & $\begin{array}{l}\text { Conducts activities aimed at increasing social cohesion } \\
\text { and liveability in urban neighbourhoods. }\end{array}$ \\
\hline 4 & Rotterdamse Munt & $\begin{array}{l}\text { Organizes workshops aimed at teaching children } \\
\text { technical skills. }\end{array}$ \\
\hline 5 & Oma's Pop-up & 2013 & $\begin{array}{l}\text { An urban garden: herbs are grown by people with poor } \\
\text { job prospects and sold to the neighbourhood. }\end{array}$ \\
\hline 6 & $\begin{array}{l}\text { Voedseltuin } \\
\text { Rotterdam }\end{array}$ & $\begin{array}{l}\text { A project aimed at combatting loneliness through } \\
\text { organizing pop-up restaurants in which the elderly } \\
\text { cook and eat together. }\end{array}$ \\
\hline 7 & $\begin{array}{l}\text { Stichting Punt } 5 \\
\text { kinderatelier }\end{array}$ & 2010 & $\begin{array}{l}\text { An urban vegetable farm providing vegetables to } \\
\text { the Rotterdam foodbank while also providing work } \\
\text { experience to people with poor job prospects. }\end{array}$ \\
\hline 8 & Hotspot Hutspot & 2003 & $\begin{array}{l}\text { Helps children through workshops to develop their } \\
\text { creative skills. }\end{array}$ \\
\hline 11 & $\begin{array}{l}\text { Stadslandbouw } \\
\text { Schiebroek-Zuid }\end{array}$ & 2012 & $\begin{array}{l}\text { A community restaurant, in which youths and } \\
\text { people with poor job respects cook meals for the } \\
\text { neighbourhood. }\end{array}$ \\
\hline Plonge Krijger & 2011 & $\begin{array}{l}\text { Conducts activities for the homeless. } \\
\text { An urban farm. }\end{array}$ \\
\hline
\end{tabular}


Table C. Social enterprises that filled in our survey (Haaglanden area)

\begin{tabular}{llcl}
\hline & Established & Description \\
\hline 1 & $\begin{array}{l}\text { ZorgMies Nederland } \\
\text { Regio Den Haag }\end{array}$ & 2015 & Matches customers and providers of health services. \\
\hline 2 & FlexStagiair & 2016 & Helps students find work experience places. \\
\hline 3 & School4Helden & 2016 & Triggers parents to organize skills workshops. \\
\hline 4 & Team is Key & 2015 & Projects for the long-term unemployed. \\
\hline 5 & Alles AnderZ & 2001 & $\begin{array}{l}\text { A management consultancy that wants to make } \\
\text { commercial companies more aware of the societal } \\
\text { impact of their actions. }\end{array}$ \\
\hline 6 & $\begin{array}{l}\text { Stichting Colours of } \\
\text { Impact }\end{array}$ & 2013 & \begin{tabular}{l} 
Empowerment for people with poor job prospects. \\
\hline
\end{tabular}
\end{tabular}


Table D. Social enterprises that filled in our survey (Drechtsteden area)

\begin{tabular}{|c|c|c|c|}
\hline & & Established & Description \\
\hline 1 & Resto van Harte & 2002 & $\begin{array}{l}\text { A restaurant where members of a community cook } \\
\text { and eat together. }\end{array}$ \\
\hline 2 & Stichting Herbouw & 2012 & $\begin{array}{l}\text { Helps people with poor job prospects develop the } \\
\text { skills of the building trade. }\end{array}$ \\
\hline 3 & $\begin{array}{l}\text { Stichting Philadephia / } \\
\text { Den Witten Haen }\end{array}$ & 2005 & A restaurant run by handicapped people. \\
\hline 4 & Erica Events & 2016 & $\begin{array}{l}\text { Helps handicapped women to become event } \\
\text { organizers. }\end{array}$ \\
\hline 5 & $\begin{array}{l}\text { SDZ-hergebruik } \\
\text { Zorghulpmiddelen }\end{array}$ & 2016 & Recycles care devices, such as walking frames. \\
\hline 6 & Stichting ANDERS & 2015 & A network of socially committed entrepreneurs. \\
\hline 7 & Werkbankdrechtsteden & 2015 & $\begin{array}{l}\text { Helps people with poor job prospects develop their } \\
\text { skills in order to find a job. }\end{array}$ \\
\hline 8 & De Eikenhof & 2016 & An urban farm. \\
\hline 9 & $\begin{array}{l}\text { Stichting Groeituinen } \\
\text { Dordrecht }\end{array}$ & 2013 & $\begin{array}{l}\text { Urban gardens where people with poor job } \\
\text { prospects can develop their skills. }\end{array}$ \\
\hline 10 & Stichting E-Wheels & 2015 & $\begin{array}{l}\text { Provides passenger traffic with electric vehicles, } \\
\text { mainly aimed at the elderly. }\end{array}$ \\
\hline 11 & Do in Dordt & 2014 & City blog about Dordrecht. \\
\hline 12 & $\begin{array}{l}\text { Intermezzo } \\
\text { Wereldwijven }\end{array}$ & 2010 & $\begin{array}{l}\text { A catering company where women from different } \\
\text { countries cook together. }\end{array}$ \\
\hline 13 & $\begin{array}{l}\text { Steunpunt } \\
\text { Drechtstadsboer }\end{array}$ & 2014 & Helps urban farms with expertise and support. \\
\hline 14 & $\begin{array}{l}\text { Stichting Wijk voor } \\
\text { Wijk }\end{array}$ & 2007 & $\begin{array}{l}\text { Provides sheltered workshops for people with poor } \\
\text { job prospects. }\end{array}$ \\
\hline
\end{tabular}

